Omni-Akuatika, 13 (2): 48-56, 2017
ISSN: 1858-3873 print / 2476-9347 online
Research Article

\title{
Morphometry Dynamical of Siombak Lake, Medan, Indonesia
}

\author{
Ahmad Muhtadi $^{1, \star)}$, Zulham A. Harahap ${ }^{1}$, Rusdi Leidonald ${ }^{1}$ \\ 1) Departemen of Aquatic Resources Management, Faculty Of Agriculture, University of Sumatera Utara (USU), \\ Medan, Indonesia \\ "Corresponding author: ahmad.muhtadi@usu.ac.id/ lobe.maddin@gmail.com
}

Received 6 January 2017; Accepted 4 June 2017; Available online 28 November 2017

\begin{abstract}
Siombak lake (28 ha area) was a salty lake located in Medan coastal, Indonesia where water fluctuation was influenced by the sea tide. The purpose of this study was to understand the dynamical of Siombaklake morphometry. The research was conducted in September 2016. Lake mapping was obtainedthrough 100 zigzaglinesand drawn with ArcMap. Bathymetry showed that the bottom of the lake was sloping at the center part of west and southeast of the lake, and steeping at north, south and east. Siombak Lake has shoreline length 2,535.78 m. It'sShoreline development index(SDI)was 2.70. Maximum length $756 \mathrm{~m}$, with maximum width $246.15 \mathrm{~m}$. Lake maximum depth was $17.7 \mathrm{~m}$ at Mean Sea Level (MSL), $18.98 \mathrm{~m}$ at highest tide and $16.71 \mathrm{~m}$ at lowest tide, with average depth $5.33 \mathrm{~m}$ at MSL, $6.30 \mathrm{~m}$ at highest tide and $4.30 \mathrm{~m}$ at lowest tide. Lake volume was 783,607.16 $\mathrm{m}^{3}$ at MSL, $829,395.52 \mathrm{~m}^{3}$ at highest tide and 355,544.14 $\mathrm{m}^{3}$ at lowest tide, water debit between from32.50 $50.17 \mathrm{~m}^{3} \mathrm{~s}^{-1}$. The water retention time between from $4.33-6.75$ hours. Siombak lake has potential for high productivity and more resistence for received the loads from surrounding area.
\end{abstract}

Keywords: ArcMap, bathymetry, morphometry, retention time, saltylake, SDI

\section{Introduction}

Lake was a water body that flooded along the year that formed naturally or artificially. Naturally could form by tectonic force, volcanic, glacier, rock decomposition (namely karst lake), flooded expose (oxbow lake), meteoroid fall etc (Loffler, 2004; Tundisi and Tundisi, 2011). Lake has specific morphology and structure that depend on basin form, physical and chemical characteristics, biological and environment interaction (Loffler, 2004; Hakanson, 2005; Barroso et al., 2014).

As morphology, the impression of shape and lake formation could be determined with morphometry (Hakanson, 1981; Wetzel and Liken, 2000). Lake physical structure determined by light distribution, heat content, wave, current and season variation. Chemical structure was a result of compound spreading like nutrition and dissolve oxygen. Meanwhile, the biological interaction has high relation with organism interaction in the water, whether with the chemical factor or among the organisms (Hakanson, 2005; Barrosoet al., 2014). Lake morphometry arranges the nutrients load, primary productivity, and secondary productivity of zooplankton, zoobenthos and nekton (Wetzel and Liken, 2000). Lake morphometry played the important role of factors causing changes in lake biological and chemical process (Hakanson, 2005). Morphometry also could be describing the potential of biological production, and determine the sensitivity level to materials load from surrounding area (Hakanson, 2005; Barroso et al., 2014).

Lake morphometry's study needed to get the impression of water physical condition vertically (subsurface dimension) and horizontally (surface dimension) (Hakanson, 1981). Lake morphometry measurement was done base on its structure like depth and elevation. In another word, lake morphometry was lake's water body shape including surface area $(\mathrm{A})$, volume $(\mathrm{V})$, average depth (Z). Lake's shoreline area topography also affected its morphometry. The structure of lake's bottom could be arranged to form bottom relief called bathymetry (Indrayaniet al., 2015).

Bathymetry was an imaginary line that joins the point with the same depth. Bathymetry map show lake's bottom relief with depth lines contour, that would give more information to surface navigation (Soeprobowati, 2012). Bathymetry needed to understand water hydrodynamics (Indrayani et al., 2015). Besides that, bathymetry data also important to a 
waterbody sustainable management (Ridoan et al., 2016).

Siombak lake was a man-made lake located in Medan coastal, Indonesia. The lake was used as the underground reservoir to people surrounding the area, flood control, fishing activity and tourism (Muhtadi et al., 2016). It was a salty lake because water fluctuation influenced by the sea tide. Therefore, it needed a dynamical study of lake morphometry as the first impression of lake physical characteristic. The purpose of this research was to understand the morphometry dynamical of Siombak lake.

\section{Materilas and Methods}

\section{Study site}

The research took place in Siombak lake, Medan city, North Sumatra Province, Indonesia. Data collection was done in September 2016. Survey equipment were Garmin Oregon 65 GPS with up to $3 \mathrm{~m}$ accuracy, Garmin 585 echo sounder, and boat.

\section{Tide survey}

The type of sea tide determined based on tidal rhythmic with Admiralty method. This research was done with measured and calculated water surface's height on sampling point. Data would be classified and analyzed to determine the tidal type of Siombak lake. Tidal data was done by scale reading on tide staff that being flooded by the sea water every one hour for 15 days. The sampling station must be in open area, did not interfere with human activities, tide staff could reach both highest tide and lowest tide, easy to observe and still flooded by water at lowest tide. Tide staff installation must be vertical and fixed (Lisnawati et al., 2013).

\section{Mapping area and bathymetry survey}

Lake mapping was done by tracking the shoreline and recorded with GPS. Bathymetry survey was done by measured lake's depth with echo sounder that being mounted on boat. Map drawing was done by making 100 lines zigzag. The lines would be represented the whole water body. Water depth data was recorded every 1 $\mathrm{m}$ along the line. Measurement data then arranged in table form, coordinate (latitude, longitude) and water depth. Then, table data transformed into spatial form and manipulated with GIS software ArcMap (Soeprobowati, 2012). Base map was using Indonesian Topography map 2013 and field survey.
Lake morphometry measurement parameters was surface dimension value including (Hakanson, 1981): maximum length $\left(L_{\text {max }}\right)$, in meter and got by measured the longest distance between two stations at the lake edge; effective maximum length $\left(L_{e}\right)$, in meter and got by measured the longest distance between two stations at the edge of lake surface without crossing island (if found); maximum width $\left(\mathrm{W}_{\max }\right)$, in meter and got by measured the longest distance between two station at the edge of lake surface and perpendicular to $L_{\text {max }}$; effective maximum width $\left(\mathrm{W}_{\mathrm{e}}\right)$, in meter and got by measured the longest distance between two stations at the edge of lake surface and perpendicular to Le; surface area $\left(A_{\circ}\right)$, in hectare was lake surface area. The surface area on bathymetry map was polygon area calculated with ArcMap; shoreline length (SL), in meter or kilometer, was the long of lake surrounding line. SL calculated from bathymetry map by using ArcMap. Lake's subsurface dimension values were (Hakanson, 1981): maximum depth $\left(Z_{\max }\right)$, in meter, was the lake's deepest depth. The direct measurement was done by the echo sounder. Average depth $(\bar{Z})$ got by averaging the lake's depth measurement.

Debit

Debit $(Q)$ was water volume that flows for certain time period. The debit measurement was done at high tide and low tide on the same channel as water entry at Terjunriver.

\section{Problem formulation}

Tidal type measured with tidal constant (tidal constant/by) that calculated with admiralty method with a formula:

$$
\mathbf{F}=\frac{A K 1+A O 1}{A M 2+A S 2}
$$

Where, Formzahl or tidal constant, $\mathrm{AK}_{1}$ solilunar constituent (diurnal tide), $\mathrm{AO}_{1}$ main lunar constituent (diurnal tide), $\mathrm{AM}_{2}$ main lunar constituent (semi-diurnal tide), $\mathrm{AS}_{2}$ main solar constituent (semi-diurnal tide).

Average width $(\overline{\mathrm{W}})$, in meter, was the ratio between surface area $\left(A_{\circ}\right)$ with a maximum length. With formula:

$\overline{\mathrm{W}}=\frac{\text { Ao }}{\mathrm{Lmax}}$

Where:: $\overline{\mathrm{W}}=$ average width $(\mathrm{m}), \mathrm{A}_{\circ}=$ lake surface area $\left(\mathrm{m}^{2}\right), \mathrm{L}_{\max }=$ maximum length (m), 
Shoreline development index (SDI), no unit, described the relation between $S L$ with surface area. If $S D I>1$, then water body has an irregular shape. If $\mathrm{SDI} \leq 1$, then water body has a regular shape. SDI formulation:

$$
\mathrm{SDI}=\frac{\mathrm{SL}}{\sqrt[2]{\frac{22}{7} \times \text { Ao }}}
$$

Where: : $S D I=$ Shoreline development index, $S L=$ shoreline length $(m), A_{o}=$ lake surface area $\left(\mathrm{m}^{2}\right)$ formulation:

Depth relative measured with

$$
\mathrm{Zr}=\frac{\mathrm{Zmax} \times \sqrt{\mathrm{n}}}{20 \times \sqrt{\mathrm{Ao}}} \times 100 \%
$$

Where: $Z_{r}=$ relative depth $(\mathrm{m}), Z_{\max }=$ maximum depth $(m), A_{0}=$ lake surface area $\left(m^{2}\right), n=$ contour total.

Average slope $(\overline{\mathrm{S}})$, in \% and describe the area with shallow water:

$$
\overline{\mathrm{S}}=\frac{1}{\mathrm{n}} \times\left(\frac{1}{2} \mathrm{xLo}+\mathrm{L} 1+\cdots+\mathrm{Ln}-1+\frac{1}{2} \mathrm{xLn}\right) \times \frac{\mathrm{Zmax}}{\mathrm{Ao}} \times 100
$$

Where $\bar{S}=$ average slope $(\%), L=$ Contour line length $(\mathrm{m}), \mathrm{n}=$ total contour in map, $Z_{\max }=$ maximum depth $(m), A_{o}=$ lake surface area $\left(m^{2}\right)$.

Lake volume development (VD), without unit, was a measurement that describes the shape of the bottom lake. It was calculated with formulation:

$$
\mathrm{VD}=\frac{\text { Ao } x \bar{Z}}{\frac{1}{3} \mathrm{x}(\mathrm{Zmax} \times \mathrm{Ao})}
$$

Where $A_{0}=$ lake surface area $\left(m^{2}\right),(\bar{Z})=$ average depth $(m), Z_{\max }=$ maximum depth $(m)$.

Lake total volume $(V)$, in $m^{3}$, was the total of water that hold by the lake. It was calculate with formulation:

$$
\mathrm{V}=\frac{\mathrm{h}}{3} \mathrm{x}\left[\sum_{\mathrm{i}-1}^{\mathrm{n}}\{(\mathrm{Ai}-1+\mathrm{Ai})+(\sqrt{(\mathrm{Ai}-1) \times \mathrm{Ai})}\}]\right.
$$

Where $\mathrm{V}=$ total volume $\left(\mathrm{m}^{3}\right), \mathrm{h}=$ contour interval $(m), A=$ contour area / layer $\left(m^{2}\right), n=$ total contour.

Debit $(\mathrm{Q})$, in $\mathrm{m}^{3} \cdot \mathrm{h}^{-1}$, was water volume that flows over certain time period. Debit was calculated with formulation:

$$
Q=A \times V
$$

Where $Q=$ water debit $\left(\mathrm{m}^{3} \cdot \mathrm{h}^{-1}\right), A=$ water tunnel area $\left(m^{2}\right), V=$ current speed $\left(m \cdot h^{-1}\right)$.

Water Retention time $\left(R_{t}\right)$, in the day, was water retention time in the lake. Retention time was calculated with formulation:

$$
\mathrm{Rt}=\frac{\mathrm{V}}{\mathrm{Q}}
$$

Where: $\mathrm{Rt}=$ retention time (hour), $\mathrm{V}=$ total volume $\left(\mathrm{m}^{3}\right), \mathrm{Q}=$ water debit $\left(\mathrm{m}^{3} \cdot \mathrm{h}^{-1}\right)$

\section{Results and Discussion}

Tide

From admiralty calculation method the $\mathrm{F}$ value in Siombak lake was 0.09. Based on that value the tide type was a semi-diurnal, which mean in one day (24 hours) there are 2 times high tide and 2 times low tide (figure 1). Tide in this area (Belawan coast) was a spread from Pacific Ocean's tide with semi-diurnal type through the South China Sea (Wyrtki, 1961). This spread would cross the shallow area that resonance system at the shallow water would influence the tide pattern (Pariwono et al., 1989). From the tide, highest water level (HWL) measurement was $191 \mathrm{~cm}$, the lowest water level (LWL) was $4 \mathrm{~cm}$. MSL was 109.77. The tidal would affect morphometry dynamical of the lake (William, 1989).

\section{Bathymetry}

The result of bathymetry mapping showed that the deepest area is in the east part of the lake, reach out $>15 \mathrm{~m}$. The deepest zone is marked by dark blue (Figure 2a, b, c). The shallowest zone $(<3 \mathrm{~m})$ is in southeast and west. In the northern part, the lake's depth was 3-6 $\mathrm{m}$ and even up to 6-9 $\mathrm{m}$. In the southern part depth of the lake was 3-6 m.

Based on layout Siombak lake contour maps were processed using Surfer 8 software clarify that in the eastern part is the deepest location. This could be seen from the more closer the contour at that location (Figure 3a, b, c). The more tightly contour shows deepened. On the contrary increasingly rare contour showed shallow depth (Indrayani et al., 2015; Suprobowati, 2012; Ridoan et al., 2016). In the southeast and west parts clearly seen the contours are very rare because at that location is an area of shallow with a depth of only up $<3$ $\mathrm{m}$. 


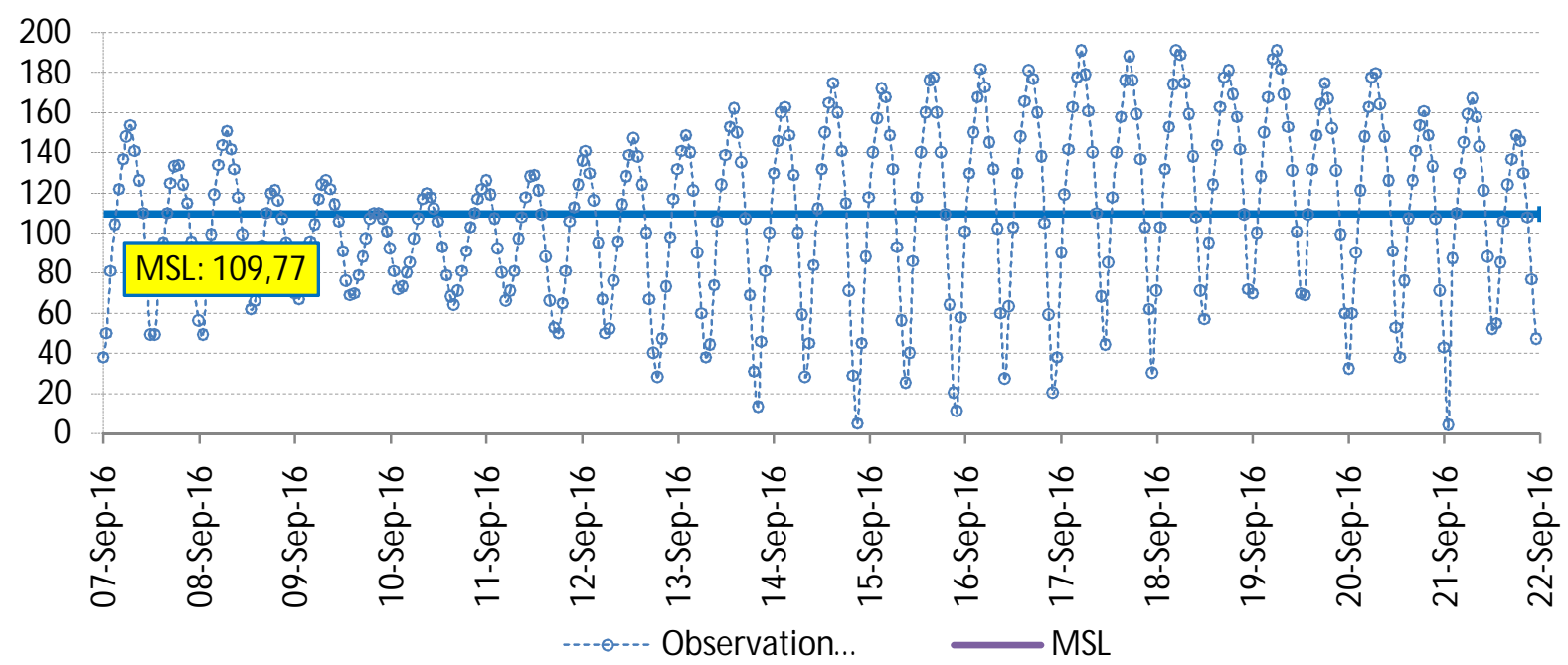

Figure 1. Graph tide in location site

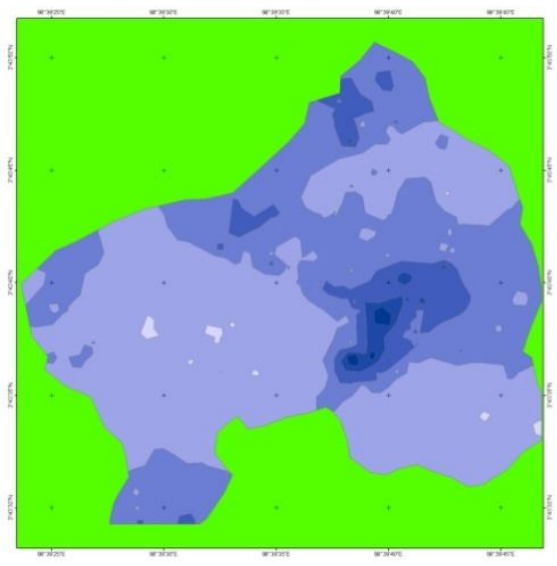

(a)
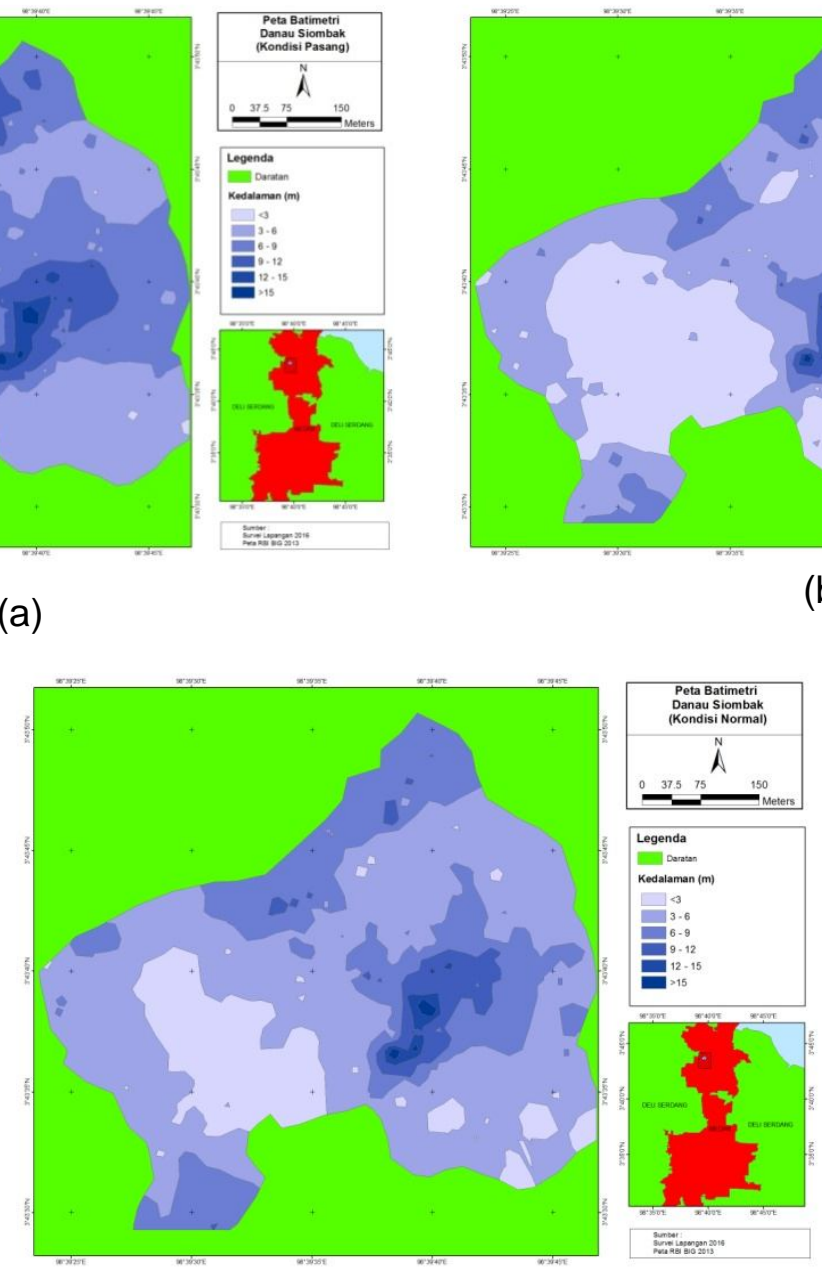

(c)
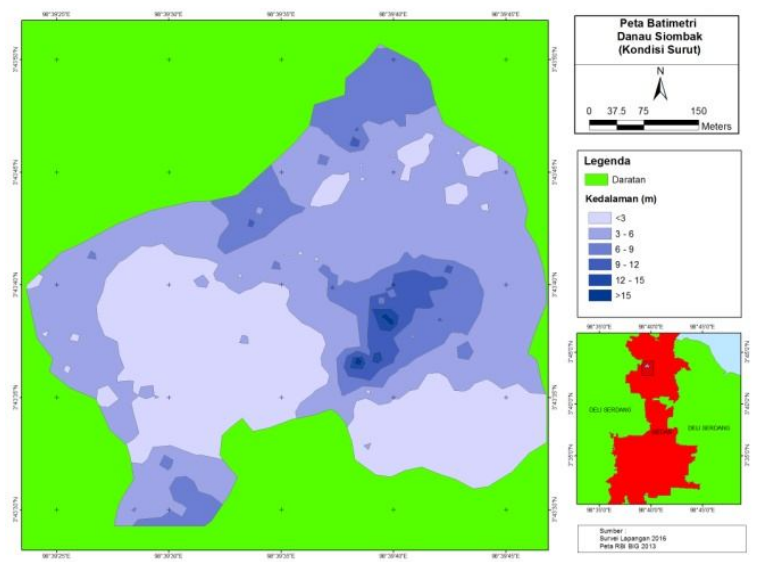

(b)

Figure 2. Bathymetry map a) high tide, b) low tide, and c) MSL 
Based on Figure 3 a, b, c above shows that there is a tidal influence on the condition of the bathymetry of the lake at high tide, low tide, and MSL. At high tide, the lowest depth was at a range of 3-6 $\mathrm{m}$ and 6-9. At low tide conditions and MSL depth of the lake's depth is generally on condition of $<3$ and 3-6 $\mathrm{m}$. This situation

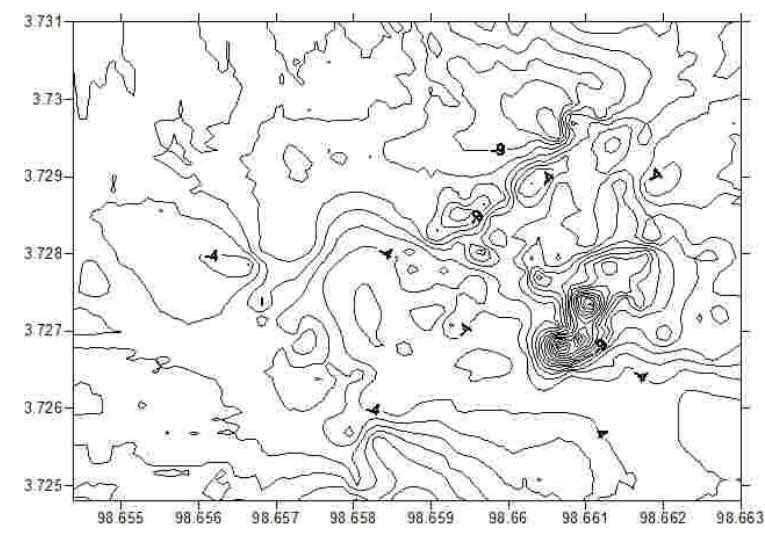

(a) match with the average depth which was 6.25 at high tide, 4.38 at low tide and 5:44 when MSL. Based on the contour pattern between high tide, low tide and MSL showed that the same pattern where the deepest area was at the east part and the shallowest area was in the southeast and the west

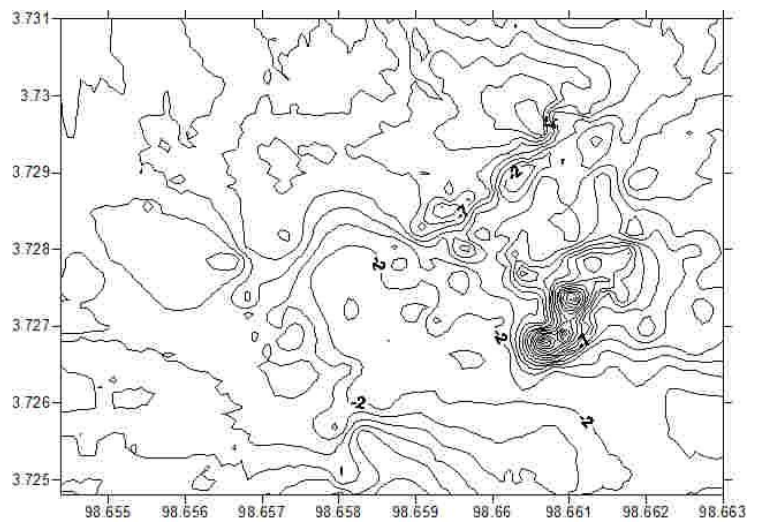

(b)

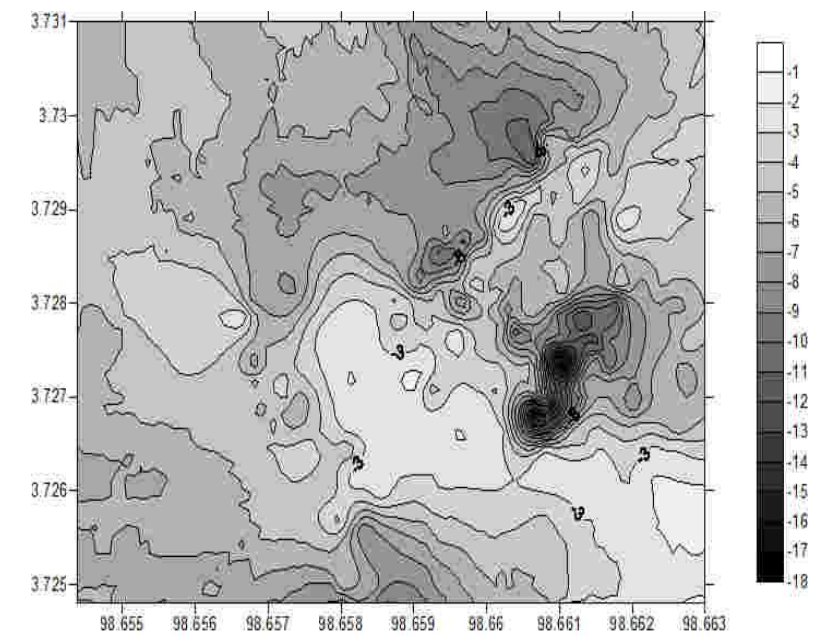

(c)

Figure 3.Depth contour a) high tide,b) low tide c) MSL

\section{Surface dimentions}

Siombak lake has a surface area of 28.10 ha with SL reached $2.53 \mathrm{~km}$. This lake has $L_{\max }$ and Le equal in the amount of $756 \mathrm{~m}$. $\mathrm{W}_{\max }$ and $\mathrm{We}$ also equal, it is $246.15 \mathrm{~m}$. The average width of the lake Siombak was 370.51 $\mathrm{m}$. Siombak Lake was categorized to the very small lake because of it area less than 100 ha and it volume less than $106 \mathrm{~m}^{3}$ (Straskraba and Tundisi, 1999). This lake is much smaller than the area of Toba Lake, which reached 112.400 ha (Lukman and Ridwansyah, 2010).

SDI of Siombak lake is 2.70. This indicates that shape of water body of Siombak lake was irregular. The irregular body shape of the lake has potential for high productivity (Wetzel, 2001). The more irregular shape of the lake cause more parts the bay from and connected to the mainland so that the possibility of nutrients entrance from the mainland would also be greater (Pratiwi et al., 2007). In general, the water of both natural and artificial lakes have SDI greater than 2 are Cilala lake (2.55) (Pratiwi et al., 2007), Toba lake (3.61) (Lukman and Ridwansyah, 2010), Kelapa Gading lake (3.55) (Ridoan et al., 2016), Pondok Lapan lake (4.93). 
Table 1. Calculation Result of surface dimension of Siombak Lake

\begin{tabular}{lllr}
\hline No. & Parameters & Unit & Nilai \\
\hline 1. & Maximum length $\left(\mathrm{L}_{\text {max }}\right)$ & $\mathrm{m}$ & 756.00 \\
2. & Efective length $\left(\mathrm{L}_{\mathrm{e}}\right)$ & $\mathrm{m}$ & 756.00 \\
3. & Maximum width $\left(\mathrm{W}_{\text {max }}\right)$ & $\mathrm{m}$ & 246.15 \\
4. & Efective Width $\left(\mathrm{W}_{\mathrm{e}}\right)$ & $\mathrm{m}$ & 246.15 \\
5. & Average width $(\mathrm{W})$ & $\mathrm{m}$ & 370.51 \\
6. & $\mathrm{SDI}$ & $\mathrm{m}$ & 2.70 \\
7. & Shore line length $(\mathrm{SL})$ & $\mathrm{m}^{2}$ & 2535.78 \\
8. & Cover area $\left(\mathrm{A}_{\mathrm{o}}\right)$ & $\mathrm{m}^{2}$ & $280,101.90$ \\
\hline
\end{tabular}

\section{Subsurface dimentions}

Siombak Lake categorized as the shallow lake with $\bar{Z} 6.25$ at high tide, 4.38 at low tide, 5.44 at MSL, even though Siombak lake's maximum depth reach $18.17 \mathrm{~m}$ at MSL, 18.96 at high tide and 16.71 at low tide. The shallow water usually has the high potential of biology productivity because of its epilimnion layer thicker than its hypolimnion layer (Barroso et al., 2014). It was supported from the $Z_{r}$ value of Siombak Lake less than $2 \%$ which $0.47 \%$ at high tide and $0.42 \%$ at low tide and $0.45 \%$ at MSL. Also clearly seen base on layout map of depth bathymetry in 3D (Figure $4 \mathrm{a}, \mathrm{b}, \mathrm{c}$ ), even at this figure clearly seen the shape of lake bottom relief. At the edge was flat and sloping especially at a southeast part. At the north and east part clearly seen lake's depth was steep. At the west part of the sloping relief and at the east the relief was steep.

The lake has basic contour relatively flat. It was supported by its slope value was 0.15 (at high tide and MSL) and 0.13 at low tide. This value described slightly flat water with a big littoral area (Figure 4). The littoral area has a high potential of biological productivity (Pratiwi et al., 2007; Bohn et al., 2011; Aldama et al., 2013). It was because littoral area has root plant that gave contribution to organic matter at the bottom; organic matter that being decomposed became nutrients source for phytoplankton and aquatic plants; and organic matter layer that accumulated at the lake bottom would be used for benthos growth
(Welch, 1952; Barroso et al., 2014; Stefanidis and Papastergiadou, 2012).

The low value of $\bar{Z}$ and $Z_{\mathrm{r}}$ indicated that Siombak lake has low-level stratification stability which easy to be steered. $Z_{r}<2 \%$ would easy to be steered its water mass, would cause layer that trend to be homogeny and the nutrients from decomposition would distribute to epilimnion layer from decomposition zone (Wetzel and Liken, 2000; Wetzel, 2001). Lake's depth has high influenced to water quality (Aldama et al., 2013; Barroso et al., 2014). It was related to lake steered $Z_{r}$ value at another lake in Indonesia was $1.39 \%$ at Situ Cilala (Pratiwi et al., 2007), Poso lake 1.18\% (Ridwan and Ridwansyah, 2009), Toba lake 1.34\% (Ridwan and Ridwansyah, 2010), and Kelapa Gading lake $0.17 \%$ (Ridoan et al., 2016), Pondok Lapan 1,40\% (unpublished data).

Volume Development value (VD) of Siombak lake was 0.47 at high tide, 0.23 at low tide and 0.46 at MSL. Parameters value of subsurface dimension were different between high tide and low tide. It explained that the tidal affected to the physical aspect of subsurface dimension especially lake's depth. It was also affected by lake's volume that would change according to how much water that enter or flow out from the lake (William, 1998; Ridoan et al., 2016). It can also be supported by data from an average slope of $0.13-0.15 \%$ which is the slope of the ramps (Syah and Hariyanto, 2013)

Table 2. Calculation Result of subsurface dimension of Siombak Lake

\begin{tabular}{lllrrr}
\hline No. & Parameter & Unit & \multicolumn{3}{c}{ Condition } \\
\hline & & & High tide & Low tide & MSL \\
\hline 1 & Mean depth $(\bar{Z})$ & $\mathrm{m}$ & 6.25 & 4.38 & 5.44 \\
2 & Maximum depth $\left(\mathrm{Z}_{\mathrm{m}}\right)$ & $\mathrm{m}$ & 18.98 & 16.71 & 18,17 \\
3 & Relative depth $\left(\mathrm{Z}_{\mathrm{r}}\right)$ & $\%$ & 0.47 & 0.42 & 0,45 \\
8 & Average slope $(\overline{\mathrm{S}})$ & $\%$ & 0.15 & 0.13 & 0,15 \\
4 & Volume development (VD) & & 0.47 & 0.23 & 0,46 \\
5 & Total Volume $\left(\mathrm{V}_{\text {tot }}\right)$ & $\mathrm{m}^{3}$ & $829,394.52$ & $355,544.14$ & $783.607,16$ \\
6 & Debit $(\mathrm{Q})$ & $\mathrm{m} / \mathrm{det}$ & 67.69 & 53.75 & - \\
7 & Water retention time (RT) & jam & & & $4,33-6,75$ \\
\hline
\end{tabular}



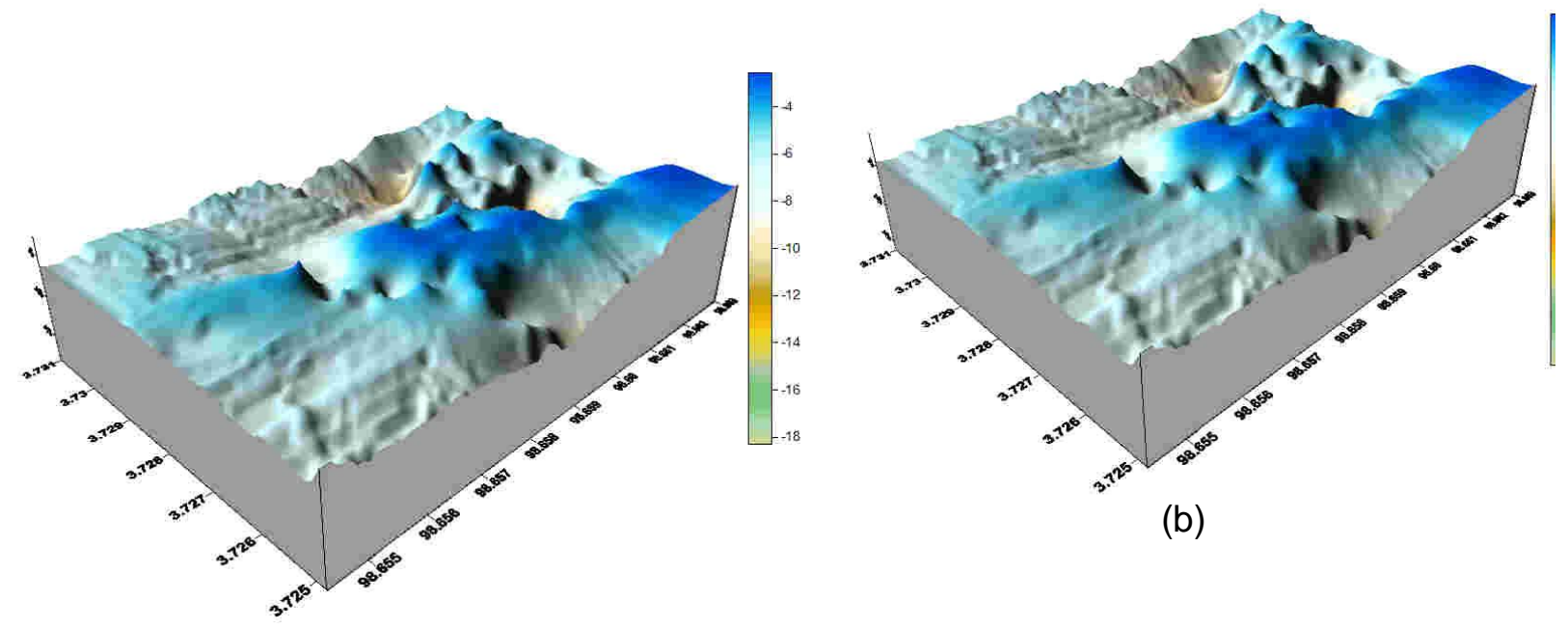

(b)

(a)

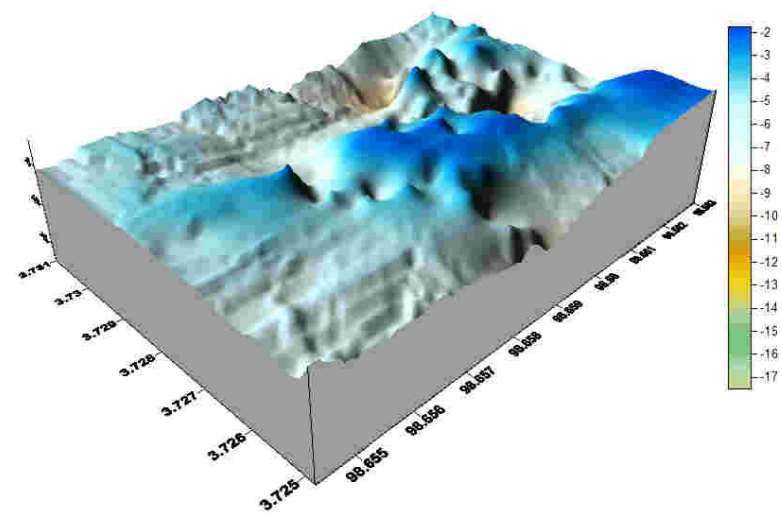

(c)

Figure 4. 3 dimensi lay out a) high tide, b) low tide, and c) MSL

\section{Discharge debit and water retention time}

Siombak lake volume was $783,607.16 \mathrm{~m}^{3}$ at MSL, $829,394.52 \mathrm{~m}^{3}$ at high tide and $355,544.14 \mathrm{~m}^{3}$ at low tide. The debit was 67.69 $\mathrm{m}^{3} \cdot \mathrm{S}^{-1}$ at high tide, $53.75 \mathrm{~m}^{3} \cdot \mathrm{S}^{-1}$ at low tide. Entry debit was influenced by the tidal, then the water that entered the lake has depended on to the tidal. That was why the water volume would also depend on the tidal condition at Belawan. That was the factor that caused the lake's volume different at high tide and low tide (Table 2).

Water retention time $\left(R_{t}\right)$ was 4.33- 6.75 hours. Siombak lake's water retention time was shorter than Cilala lake at 8 days (Pratiwi et al., 2007), PondokLapan lake at 11-12 day (unpublished data), Kelapa Gading lake at 225 days (Ridoan et al., 2016), and totally different compare to Poso lake and Toba lake was 7.21 and 81.24 years (Ridwan and Lukmansyah,
2009; 2010). The higher retention time value $\left(R_{t}\right)$, then the longer water stay at the lake. Then the chance of organic matter and nutrients in the water also bigger (Pratiwi et al., 2007). Siombak lake retention time (Rt) categorized short because it was influenced by the tidal, and the chance of organic matter on the water only $4-7$ hours period. The low value of retention time $\left(R_{t}\right)$ also caused an only small possibility of suspended material at the water to be settled.

\section{Conclusion}

Siombak lake has potential for high productivity and more resistence for received the loads from surrounding area. Morphometry condition of Siombak lake was very dynamics because influenced by the tidal and easy to be steered because it was shallow and flat. 


\section{Acknowledgments}

The authors gratefully acknowledge that the present research is supported by the University Of Sumatera Utara. The support is under the research grant TALENTA USU of Year 2016. Thanks also go to Riski Ridoan who helped process data.

\section{References}

Aldama G. R., Palafox, J. T. P., Cruz, L. F. G., Hernández, D ;O., Díaz, J.A., Arredondo-Figueroa, J.L. 2013. Morphometric Characteristics of tropical shallow reservoir used for aquaculture and agriculture in the Mexican Plateau. Revista Bio Ciencias 2 (2): 83-88.

Bohn, V. Y., Perillo, G. M. E., Picollo, M.C. 2011.Distribution and morphometry of shallow lakes in a temperate zone (Buenos Aires Province, Argentine).Limnetica 30 (1): 89 - 102.

Barroso, G. F., Goncalves, M.A., Fabio da C. Garcia. 2014. The Morphometry of lake Palmas, a deep natural lake in Brazil. PLoS One 9 (11) 1-13.

Hakanson, L. 1981. A Manual of lake morphometry. Springer-Verlag. Berlin. Heiderberg.1-73.

Hakanson, L. 2005. The Importance of lake morphometry and catchment characteristic in limnology - ranking based on statistical analysis. Hydrobiologia 541: 117- 137.

Loffler H. 2004. The origin of lake basins. In the lakes handbook vol. 1 Limnology And Limnetic Ecology. P.E. O'Sullivan and C. S. Reynolds (Ed.). Blackwell Publishing company. Victoria, Australia: 8-57.

Indrayani, E., Nitimulyo, K.H., Hadisusanto, S., Rustadi. 2015. Bathymetric map of Lake Sentani Papua. Depik 4 (3): 116-120.

Lisnawati, L. A, Rochaddi,B., Ismunarti, D. H. 2013. Studi tipe pasang surut di pulau Parang kepulauan Karimun Jawa, Jepara, Jawa Tengah.Buletin Oseanografi Marina 2 (2): 61-67.

Lukman, I. Ridwansyah. 2009. Study of lake Poso physical condition and prediction of its aquatic ecosystem characteristics. Limnotek 16 (2) : 64-73.

Lukman, I. Ridwansyah. 2010. Study of morphometry condition and several stratification parameters of lake Toba. Limnotek 17 (2): 158-170.

Muhtadi, A.,Yunasfi, R.,Leidonald, S. D., Sandy, A.,Junaidy, A. T.,Daulay. 2016. Limnologi calstatus of lake Siombak, Medan, North Sumatra. Oseanologi dan Limnologi di Indonesia1 (1): 39-55.

Soeprobowati, T. R. 2012. Peta batimetri danau Rawapening.Bioma 14 (2): 75-78.

Straskraba, M., Tundisi, J.G. 1999. Guidelines of lake management vol. 9, Management of inlad saline water.International Lake Environment Committee Foundation. Shiga, Jepang. 29-34.

Stefanidis, K., Papaster giadou, E. 2012. Relationships between lake morphometry, water quality, and aquatic macrophytes, in Greek lakes. University of Patras. Greece. Fresenius Environmental Bulletin 21 (10): 3018 3026.

Pariwono, J.I. 1989, Pasang surut di Indonesia, di dalam: O.S.R. Ongkosono, Suyarso, (Ed.). Pasang surut, Pusat Penelitiandan Pengembangan Oseanologi LIPI. Jakarta

Pratiwi, N. T. M., Adiwilaga, E.M., Basmi, J., Krisanti, M., Hadijah, O., Wulandari, P.K. 2007. The Limnologi calstatus of Cilala reservoir based on physical,chemical, and biological parameters.Jurnal Perikanan 9 (1): 82-94.

Ridoan, R., Muhtadi, A., Patana, P. 2016. Morfometri danau Kelapa Gading kota Kisaran, kabupaten Asahan provinsi Sumatera Utara. Depik 5(2): 77-84.

Straskraba, M., Tundisi, J.G. 1999. Guidelines of lake management Vol. 9. International Lake Environment Committee Foundation. Shiga, Jepang. 229 p.

Syah, M. W., Haryanto, T. 2013. Klasifikasi kemiringan lereng dengan menggunakan pengembangan Sistem Informasi Geografis sebagai evaluasi kesesuaian landasan pemukiman berdasarkan Undang-Undang tata ruang dan metode Fuzzy. Institut Teknologi Sepuluh Nopember. Teknik Pomits 10 (10): 1-6.

Tundisi J.G., Tundisi, T.M. 2011. Limnology.Taylor \& Francis Group. Boca Raton, Brazil. 37-58.

Welch, P.S. 1952. Limnology. Second edition. McGraw-Hill Book Company,Inc. New York. 3-15. 
Wetzel R.G., Gliken, G.E. 2000. Limnological analyses 3 edition. Springer Science Business Media New York. 1-14.

Wetzel, R. G. 2001. Limnology lake and river ecosystems. Academic Press. California. 34-41.

William, W. D. 1998. Guideline of lake management, vol. 6. Reservoir water quality management. International Lake Environment Committee Foundation. Shiga, Jepang 69-82.

Wyrtki, K. 1961. Physical oceanography of the Southeast Asian waters. Naga Report 2: 1-195. 